\title{
Identifikasi Ketebalan Tanah Gambut Lahan Permukiman di Sungai Raya Dalam dengan Metode Geolistrik Resistivitas \\ Devia Rolita ${ }^{a^{*}}$, Boni Pahlanop Lapanporoa, Zulfian ${ }^{\mathrm{b}}$
}

aProgram Studi Fisika, FMIPA Universitas Tanjungpura, Pontianak

bProgram Studi Geofisika, FMIPA Universitas Tanjungpura, Pontianak

*Email : vividevi866@gmail.com

\begin{abstract}
Abstrak
Telah dilakukan penelitian mengenai identifikasi ketebalan tanah gambut lahan permukiman di Sungai Raya Dalam. Resistivitas tanah gambut diukur menggunakan metode Geolistrik Resistivitas konfigurasi Wenner-Schlumberger. Pengambilan data dilakukan sebanyak 4 lintasan dengan panjang lintasan 62 meter dan jarak antar elektroda 2 meter. Data resistivitas tanah gambut dipetakan dalam bentuk 2D menggunakan perangkat Res2Dinv. Berdasarkan distribusi nilai resistivitas dapat diinterpretasikan bahwa struktur lapisan bawah permukaan lahan gambut di Sungai Raya Dalam terdiri dari tanah gambut dan lempung, Hasil penelitian menunjukkan lapisan gambut memiliki nilai resistivitas 29,4 hingga 151,6 $\Omega \mathrm{m}$. Ketebalan lapisan tanah gambut bervariasi mulai dari 4 hingga 7,91 meter.
\end{abstract}

Kata Kunci: Gambut, Metode Resistivitas

\section{Pendahuluan}

Lahan gambut merupakan salah satu sumber daya alam yang mempunyai fungsi hidro-orologi dan fungsi lingkungan lain yang penting bagi kehidupan seluruh mahluk hidup. Lahan gambut di Kabupaten Kubu Raya memiliki luas sekitar 523.400 ha atau sekitar $76 \%$ dari luas lahan di kabupaten ini dan dijumpai di dataran pantai yang sebagian tersebar di wilayah Sungai Rasau dan Delta Kapuas yang merupakan dataran atau kubah gambut (Wahyunto dkk, 2005) [1].

Beberapa penelitian terkait lahan gambut dan metode geolistrik resistivitas antara lain: Sirait dkk (2015) yang mengidentifikasi struktur lapisan tanah gambut sebagai informasi awal rancang bangunan dengan metode geolistrik 3D. Penelitian ini menghasilkan citra 2D yang menunjukkan ketebalan maksimum tanah gambut untuk masing-masing lintasan mulai dari lintasan 1 hingga lintasan 5 secara berurutan adalah 2-9 meter dengan tingkat kesalahan hampiran 6-17\%. Pada pencitraan 3D terlihat lapisan tanah gambut terdistribusi hingga kedalaman 8,68 m pada bagian utara dan barat daerah pengukuran dengan tingkat kesalahan hampiran 10,8\%. Hidayat dkk (2015) mengidentifikasi lokasi bedrock menggunakan metode geolistrik konfigurasi Wenner sebagai bahan acuan perancangan pondasi pembangunan gedung di daerah Sampit Kalimantan Tengah. Hasil penelitian tersebut menunjukkan lapisan Bedrock berada pada kedalaman antara 6,38-9,4 meter dari permukaan tanah dengan nilai resistivitas berkisar 9,84-19,2 $\Omega \mathrm{m}$.
Informasi mengenai tanah gambut mesti di perbaharui secara berkala agar dapat menunjang pembangunan berkelanjutan terutama di bidang permukiman dengan memanfaatkan tanah gambut. Dikarenakan pentingnya mengetahui informasi mengenai ketebalan lapisan tanah gambut di lahan tersebut, maka sebelum melakukan peralihan fungsi lahan gambut menjadi lahan permukiman perlu adanya penelitian terkait identifikasi ketebalan tanah gambut lahan permukiman. Hal ini yang melatarbelakangi peneliti mengkaji identifikasi ketebalan tanah gambut lahan permukiman di Sungai Raya Dalam dengan metode geolistrik resistivitas.

Metode geolistrik resisitvitas merupakan salah satu metode geofisika yang memanfaatkan sifat resistivitas tanah untuk mengetahui struktur bawah permukaan bumi. Terdapat berbagai macam bentuk konfigurasi elektroda pada metode geolistrik resistivitas. Salah satu konfigurasi yang sering digunakan adalah konfigurasi Wenner-Schlumberger. Seperti penelitian sebelumnya metode geolistrik konfigurasi Wenner-Schlumberger mampu mengidentifikasi kedalaman tanah. Dalam penelitian ini digunakan metode geolistrik 2D konfigurasi Wenner-Schlumberger.

\section{Metodologi}

\subsection{Waktu dan Tempat Penelitian}

Penelitian ini dimulai pada bulan April s.d Juli 2019. Penelitian ini dilakukan di Komplek Korpri Sungai Raya, Kabupaten Kubu Raya, Kalimantan Barat, dengan koordinat $0^{\circ} 06^{\prime} 0,117^{\prime \prime}$ LS dan $109^{\circ} 20^{\prime} 50,34^{\prime \prime}$ BT. Lintasan yang 
dipergunakan pada penelitian ini sebanyak 4 lintasan. Lintasan 1, 2, dan 3 memiliki panjang 62 meter yang berarah $\mathrm{N} 154^{\circ} \mathrm{E}$ sedangkan lintasan 4 memiliki panjang 42 meter yang memiliki arah $\mathrm{N} 229^{\circ} \mathrm{E}$.

Lintasan 1, 2, dan 3 masing-masing berjarak $10 \mathrm{~m}$, sedangkan lintasan 4 memotong lintasan 1 , 2 dan 3. Lintasan 1 berada pada koordinat $0^{\circ} 06^{\prime} 01,60^{\prime \prime}-0^{\circ} 06^{\prime} 02,95^{\prime \prime}$ LS dan $109^{\circ} 20^{\prime} 47,77^{\prime \prime}-$ $109^{\circ} 20^{\prime} 49,13^{\prime \prime}$ BT. Koordinat Lintasan 2 adalah $0^{\circ} 06^{\prime} 01,19^{\prime \prime}-0^{\circ} 06^{\prime} 02,63^{\prime \prime}$ LS dan $109^{\circ} 20^{\prime} 47,89^{\prime \prime}-$ $109^{\circ} 20^{\prime} 49,51^{\prime \prime}$ BT. Lintasan 3 berada di $0^{\circ} 06^{\prime} 00,94^{\prime \prime}-0^{\circ} 06^{\prime} 02,44^{\prime \prime}$ LS dan $109^{\circ} 20^{\prime} 48,16^{\prime \prime}-$ $109^{\circ} 20^{\prime} 49,76^{\prime \prime}$ BT. Lokasi koordinat untuk Lintasan 4 adalah $0^{\circ} 06^{\prime} 01,27^{\prime \prime}-0^{\circ} 06^{\prime} 02,31^{\prime \prime}$ LS dan $109^{\circ} 20^{\prime} 49,71^{\prime \prime}-109^{\circ} 20^{\prime} 48,48^{\prime \prime}$ BT.

\subsection{Peralatan}

Adapun peralatan yang digunakan dalam penelitian ini adalah:

1) Resistivity meter

2) Elektroda (24 elektroda)

3) Kabel penghubung

4) Meteran

5) GPS

6) Aki

\subsection{Pengambilan Data}

Langkah-lngkah yang dilakukan saat pengambilan data adalah sebagai berikut:

1) Menyiapkan peralatan

2) Menentukan koordinat di tiap lintasan dengan jarak antar lintasan sebesar 10 meter.

3) Menentukan lintasan penelitian dengan mengukur panjang lintasan dan jarak antar elektroda menggunakan meteran.

4) Menancapkan elektroda dengan jarak 2 meter per elektroda.
5) Menghubungkan elektroda dengan resistivity meter yang telah dirangkai dan dihubungkan dengan aki sebagai sumber listrik.

6) Menginjeksikan arus listrik dari resistivity meter melalui elektroda yang telah terhubung dengan kabel penghubung.

7) Nilai arus dan beda potensial yang muncul akan terekam secara otomatis pada resistivity meter.

8) Resistivity meter akan berhenti secara otomatis jika nilai arus dan beda potensial telah didapatkan untuk setiap datum.

\subsection{Metode Geolistrik}

Metode geolistrik adalah salah satu metode geofisika yang mempelajari sifat aliran listrik di bawah permukaan bumi. Metode geolistrik terdiri dari beberapa macam salah satunya adalah metode geolistrik resistivitas (tahanan jenis). Metode geolistrik resistivitas merupakan salah satu metode geofisika yang memanfaatkan sifat resistivitas untuk menyelidiki keadaan di bawah permukaan bumi. Pada metode ini arus listrik dialirkan ke dalam bumi melalui dua elektroda arus, kemudian besarnya potensial yang disebabkannya diukur di permukaan bumi melalui dua buah elektroda potensial, sehingga nilai resistivitasnya dapat dihitung. Besarnya beda potensial antara elektroda P1P2 dan C1C2 dapat dihitung dengan menggunakan Persamaan 1.

$$
\begin{aligned}
& \Delta V=V P_{1}-V P_{2} \\
& \Delta V=\frac{I \rho}{2 \pi}\left(\frac{1}{r_{1}}-\frac{1}{r_{2}}-\frac{1}{r_{3}}+\frac{1}{r_{4}}\right)
\end{aligned}
$$

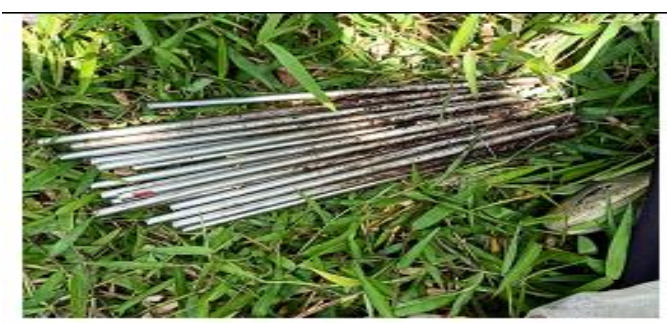

(a)

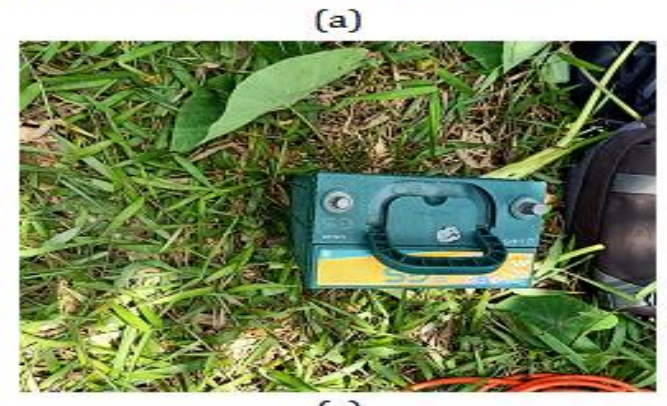

(c)

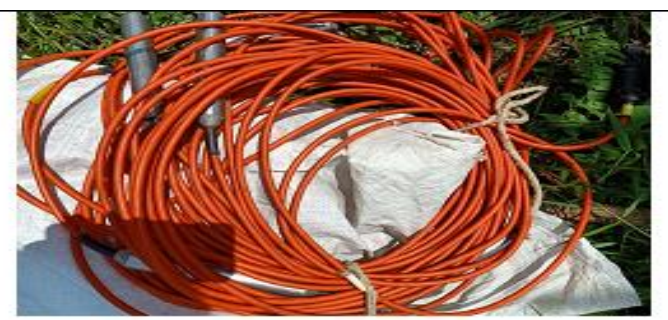

(b)

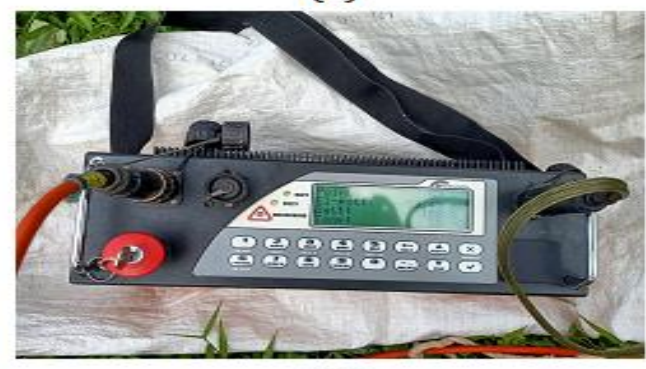

(d)

Gambar 1. Alat: elektroda (a), kabel penghubung (b), aki (c), dan resistivity meter (d) 


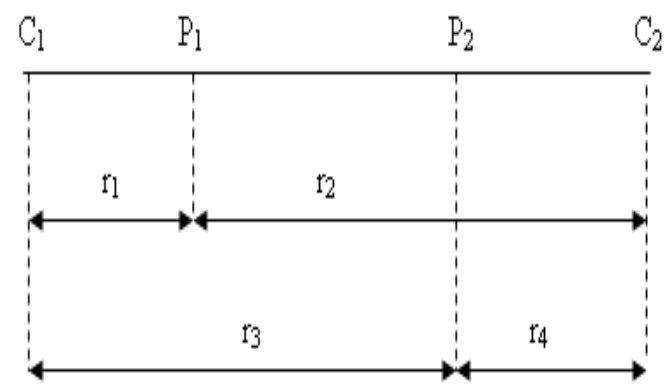

Gambar 2. Susunan elektroda ganda di permukaan homogen [4]

Konfigurasi yang digunakan dalam penelitian ini adalah konfigurasi WennerSchlumberger. Konfigurasi WennerSchlumberger adalah konfigurasi dengan sistem aturan spasi yang konstan dengan catatan faktor " $n$ " untuk konfigurasi ini adalah perbandingan jarak antara elektroda C1-P1 (C2-P2) dengan spasi antara P1-P2 seperti pada Gambar 2. Jika jarak antara potensial (P1 dan P2) adalah a, maka jarak antara elektroda arus (C1 dan C2) adalah 2na+a. Proses penentuan resistivitas mengunakan 4 buah elektroda yang diletakkan dalam sebuah garis lurus. Nilai resistivitas semu dihitung berdasarkan Persamaan 2.

$$
\rho_{a}=n(n+1) \pi a \frac{\Delta V}{I}
$$

Dari Hasil pengolahan data maka didapat nilai penampang resistivitas. Penampang lintang ini berisi sebaran nilai resistivitas yang diwakili oleh warna-warna yang berbeda. Dengan demikian dapat dianalisis kedalaman tanah gambut yang ditunjukkan dengan nilai resistivitasnya, dengan membandingkannya dengan Tabel 1

Tabel 1 Nilai resistivitas batuan dan mineral bumi

\begin{tabular}{cc}
\hline Material & Resistvitas $(\Omega \mathrm{m})$ \\
\hline Air Asin $^{5}$ & 0,2 \\
Air tanah $^{5}$ & $0,5-200$ \\
Lempung $^{5}$ & $1-100$ \\
Pasir $^{5}$ & $1-1000$ \\
Tembaga $^{5}$ & $1-1,7$ \\
Magnesium $^{5}$ & 4,2 \\
Bijih besi $^{5}$ & $0,1-25$ \\
Khrom $^{5}$ & 13,2 \\
Alluvium $^{5}$ & $10-800$ \\
Mangan $^{5}$ & $44-160$ \\
Kerikil $^{5}$ & $100-600$ \\
Batu pasir $^{5}$ & $50-500$ \\
Gambut $^{6}$ & $25,3-108$ \\
Lanau $^{5}$ & $10-200$ \\
Batu lumpur $^{5}$ & $3-70$ \\
\hline
\end{tabular}

Sumber: 1. Telford dkk [5]

2. Santoso dkk [6]

\section{Hasil dan Pembahasan}

Menurut Pokja Sanitasi Kabupaten Kubu Raya (2013) berdasarkan posisinya seluruh areal studi terletak pada formasi alluvium dan endapan rawa. Formasi ini terdiri dari kerikil, pasir, lanau, lumpur dan gambut. Lokasi penelitian terletak di Komplek Korpri Sungai Raya Dalam Kabupaten Kubu Raya dengan koordinat $0^{\circ} 06^{\prime} 04,17^{\prime \prime}$ LS dan $109^{\circ} 20^{\prime} 50,34^{\prime \prime}$ BT. Jenis tanah pada lokasi penelitian adalah tanah gambut yang berada di sekitar permukiman. Metode yang digunakan dalam penelitian ini adalah metode geolistrik resistivitas konfigurasi Wenner-Schlumberger.

Data yang didapat dari pengambilan data di lapangan diolah menggunakan Res2Dinv untuk mendapatkan model distribusi tahanan jenis bawah permukaan di setiap lintasan dan kedalaman lapisan tanah. Model distribusi tahanan jenis bawah permukaan dapat mencerminkan kondisi bawah permukaan lintasan pengukuran, sehingga dapat dilakukan interpretasi kondisi bawah permukaannya. Hasil pengolahan data Res2Dinv ditampilkan dalam bentuk penampang 2D dengan nilai resistivitas yang berbeda tergantung dari material bawah permukaan tanah pada daerah penelitian.

\subsection{Interpretasi Data}

3.1.1 Interpretasi data lintasan 1

Lintasan 1 merupakan lintasan yang mengarah $\mathrm{N} 135^{\circ}$ E. Proses inversi menggunakan Res2Dinv, didapatkan eror sebesar $6,1 \%$ pada iterasi kelima. Penampang 2D resisitivitas di bawah permukaan tanah pada Lintasan 1 dapat dilihat pada Gambar 3.

Gambar 3 merupakan penampang resisitivitas 2D pada Lintasan 1. Berdasarkan penampang resistivitas tersebut nilai resistivitas pada Lintasan 1 sebesar 2,2 s.d 11,61 $\Omega$ m. RMS error dari model penampang resistivitas ini sebesar 6,1\% pada iterasi ke-5. Gambar 1 juga memperlihatkan kedalaman interpretasi struktur lapisan pada Lintasan 1 hingga 11,5 m. Interpretasi data pada Lintasan 1 dikelompokkan menjadi 3 lapisan. Lapisan A dengan resistivitas 29,4 s.d 41,16 $\Omega$ m yang diinterpretasikan sebagai lapisan tanah gambut. Pada lapisan tanah gambut ini teridentifikasi nilai terdangkal pada kedalaman $4 \mathrm{~m}$ dan terdalam pada kedalaman $6,37 \mathrm{~m}$. Rentang nilai resistivitas pada lapisan B berkisar antara 10,4 s.d 29,8 $\Omega$ m. Lapisan B diinterpretasikan sebagai lapisan tanah lempung bercampur pasir yang berada pada kedalaman 4 meter hingga $11,5 \mathrm{~m}$. Secara umum nilai resistivitas tanah lempung adalah 1 s.d $100 \Omega \mathrm{m}$ [4]. Lapisan C memiliki nilai resistivitas 2,2 s.d $10,4 \Omega$ m yang diinterpretasikan sebagai lapisan 


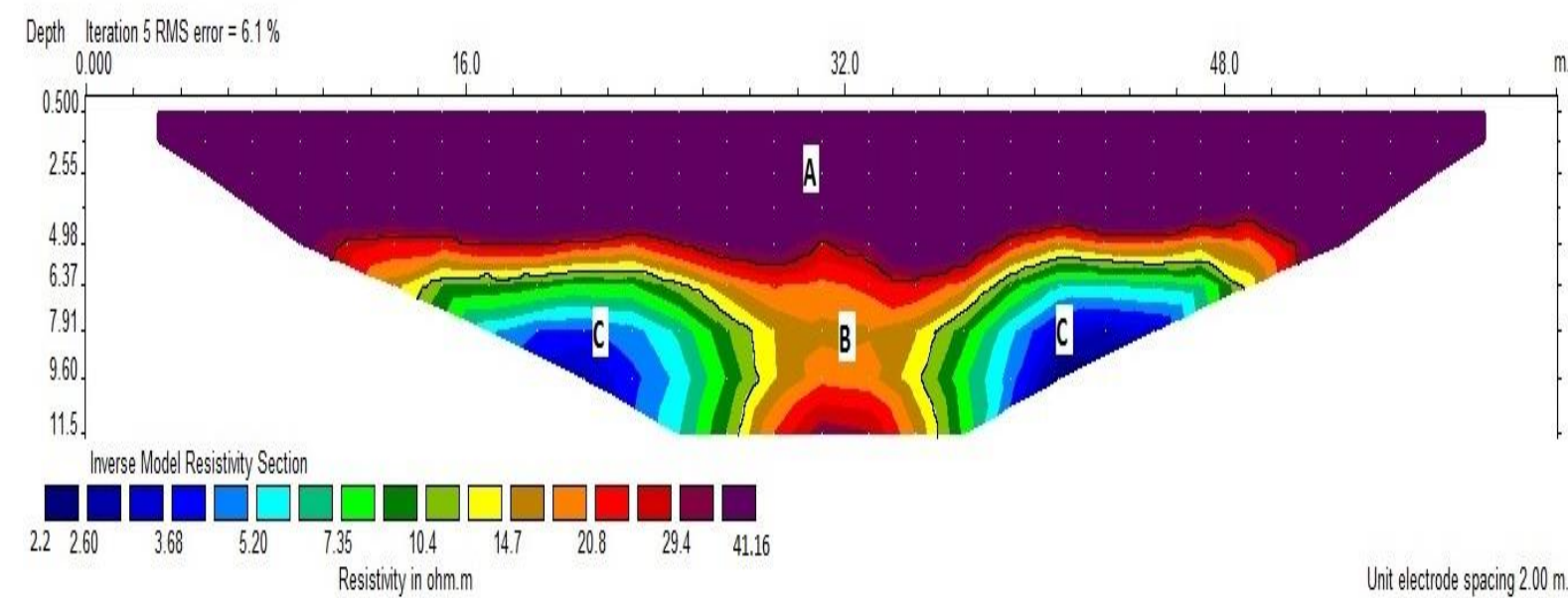

Gambar 4. Penampang resistivitas pada Lintasan 1

pasir pada kedalaman 6 hingga 11,5 m yang tersebar pada jarak 16 hingga $26 \mathrm{~m}$ dan 36 hingga $48 \mathrm{~m}$. Secara umum nilai lapisan ini lebih konduktif dikarenakan terakumulasi fluida (air).

\subsubsection{Interpretasi Data Lintasan 2}

Lintasan 2 merupakan lintasan yang mengarah $\mathrm{N} 135^{\circ} \mathrm{E}$ dengan titik awal Lintasan 2 berada pada koordinat $0^{\circ} 06^{\prime} 01,19^{\prime \prime}$ LS dan $109^{\circ} 20^{\prime} 47,89^{\prime \prime}$ BT dengan titik akhir $0^{\circ} 06^{\prime} 02,63^{\prime \prime}$ LS dan $109^{\circ} 20^{\prime} 49,51^{\prime \prime}$ BT.

Gambar 5 merupakan penampang resistivitas 2D Lintasan 2. Berdasarkan penampang resistivitas tersebut nilai resistivitas pada Lintasan 2 sebesar 0,95 s.d 46,3 $\Omega \mathrm{m}$. Dari model penampang resistivitas ini diperoleh RMS Error sebesar 9,9\% pada iterasi ke-5.

Gambar 5 juga memperlihatkan kedalam interpretasi struktur lapisan pada Lintasan 2 hingga 11,5 meter. Interpretasi data pada Lapisan 2 dikelompokkan menjadi 3 lapisan yakni lapisan A diinterpretasikan sebagai tanah gambut dengan nilai resitivitas sebesar 29,4 s.d $46,3 \Omega \mathrm{m}$. Pada lapisan ini teridentifikasi nilai terdangkal pada kedalaman 3,7 meter dan terdalam pada kedalaman 6,37 meter. Lapisan B diinterpretasikan sebagai lapisan tanah lempung dengan nilai resitivitas 7,30 s.d 29,2 $\Omega \mathrm{m}$. Nilai resitivitas 0,95 s.d 7,30 $\Omega \mathrm{m}$ diinterpretasikan sebagai lapisan air tanah pada Lapisan C. Nilai resistivitas air tanah secara umum sebesar 0,5 s.d $200 \Omega \mathrm{m}$ seperti yang terlihat pada Tabel 1 [4]. Lapisan C tersebar sebanyak dua titik di sepanjang lintasan dengan jarak 16 s.d 24 meter dan 38 s.d 48 meter.

\subsubsection{Interpretasi Data Lintasan 3}

Titik awal Lintasan 3 berada pada koordinat $0^{\circ} 06^{\prime} 00,94 "$ LS dan $109^{\circ} 20^{\prime} 48,16^{\prime \prime}$ BT dengan titik akhir berada pada $0^{\circ} 06^{\prime} 02,44^{\prime \prime}$ LS dan $109^{\circ} 20^{\prime} 49,76^{\prime \prime}$ BT. Lintasan 3 mengarah N $135^{\circ} \mathrm{E}$ pada lokasi penelitian. Hasil inversi Lintasan 3 menunjukkan penampang 2D yang dapat dilihat pada Gambar 6 dengan eror sebesar 9,4\% pada iterasi kelima. Gambar 6 menunjukkan nilai resistivitas yang terukur sebesar 1,03 s.d 47,25 $\Omega$ m dengan kedalaman yang terukur 11,5 meter. Lapisan A diinterpretasikan sebagai lapisan tanah gambut dengan nilai resistivitas 29,4 s.d $47,25 \Omega \mathrm{m}$.

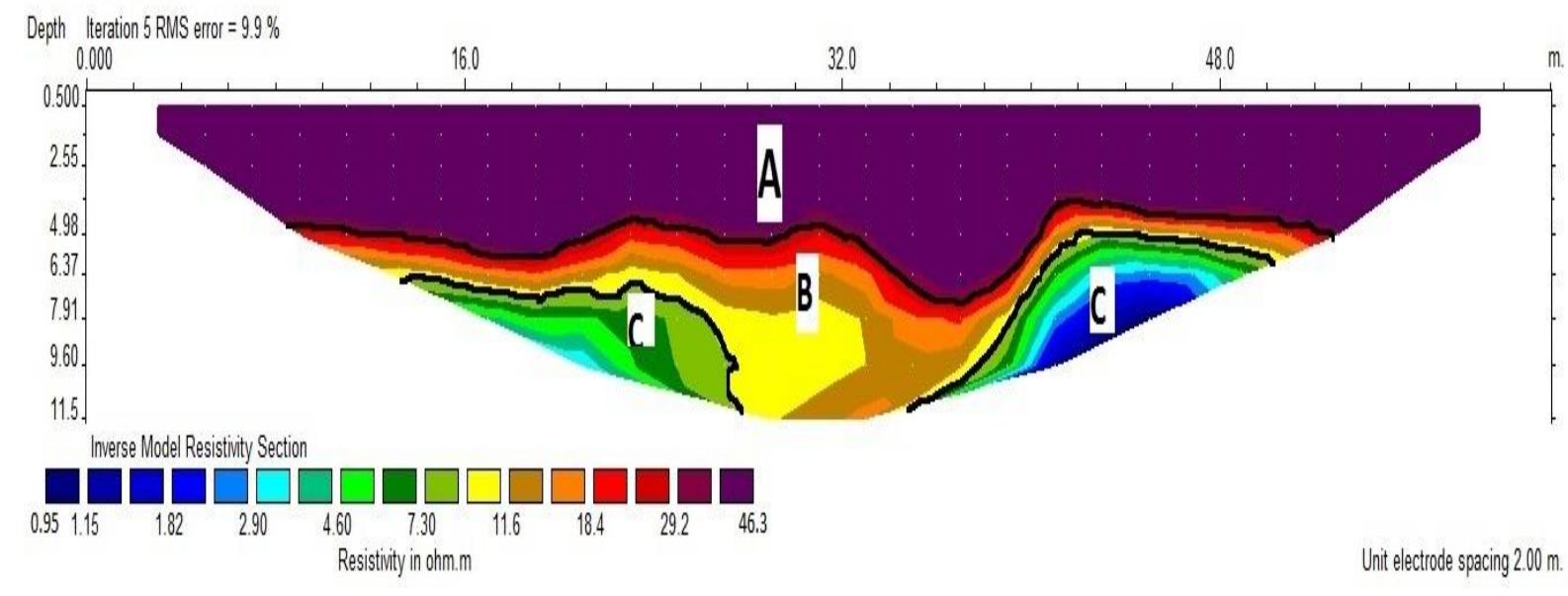

Gambar 5. Penampang resistivitas pada Lintasan 2 
Pada lapisan ini teridentifikasi nilai terdangkal pada kedalaman 4 meter dan terdalam pada kedalaman 5,6 meter. Interpretasi lapisan B dengan nilai resitivitas 7,87 s.d 29,4 $\Omega \mathrm{m}$ sebagai lapisan tanah lempung. Lapisan $\mathrm{C}$ dengan nilai resistivitas 1,03 s.d $7,87 \quad \Omega m$ diinterpretasikan sebagai air tanah. Lapisan $\mathrm{C}$ tersebar sepanjang lintasan dengan jarak 13 s.d 24 meter dan 32 s.d 46 meter. Nilai reisistivitas pada Lapisan $\mathrm{C}$ lebih rendah daripada nilai resistivitas lapisan A dan B. Hal ini diindikasikan bahwa pada lapisan C merupakan lapisan akuifer.

\subsubsection{Interpretasi Data Lintasan 4}

Lintasan 4 merupakan lintasan yang mengarah N $229^{\circ}$ E pada lokasi penelitian. Titik awal Lintasan 4 terletak pada koordinat $0^{\circ} 06^{\prime} 01,24^{\prime \prime}$ LS dan $109^{\circ} 20^{\prime} 49,71^{\prime \prime}$ BT dengan titik akhir $0^{\circ} 06^{\prime} 02,31^{\prime \prime}$ LS dan $109^{\circ} 20^{\prime} 48,48^{\prime \prime}$ BT. Proses inversi menggunakan Res2Dinv didapatkan eror sebesar $6,5 \%$ pada iterasi kelima. Penampang 2D resisitivitas di bawah permukaan tanah pada Lintasan 4 dapat dilihat pada Gambar 7.

Nilai resistivitas yang terukur sebesar 0,44 s.d 151,6 $\Omega$ m dengan kedalaman 7,91 meter seperti yang ditunjukkan oleh Gambar 4. Seperti lintasan sebelumnya, Lintasan 4 juga dikelompokkan menjadi 3 lapisan. Lapisan A dengan nilai resitivitas 29,4 s.d 151,6 $\Omega \mathrm{m}$ diinterpretasikan sebagai lapisan gambut. Pada lapisan tanah gambut ini teridentifikasi nilai terdangkal pada kedalaman 4 meter dan terdalam pada kedalaman 7,91 meter. Lapisan B dengan nilai resistivitas 9,46 s.d 29,4 $\Omega \mathrm{m}$ diinterpretasikan sebagai lapisan tanah lempung. Lapisan $\mathrm{C}$ dengan nilai resistivitas 0,44 s.d 9,46 $\Omega \mathrm{m}$ yang diinterpretasikan sebagai lapisan air tanah. Lapisan $C$ tersebar pada jarak 13 s.d 19 meter.

\subsection{Analisis Ketebalan Tanah Gambut}

Berdasarkan Lintasan 1 hingga Lintasan 4, lapisan gambut mencapai kedalaman hingga 6,37 meter. Ketebalan lapisan gambut tidak merata yaitu dari rentang 0,6 meter hingga 6,37 meter. Lapisan gambut lebih resistif dibandingkan lapisan dibawahnya. Hal itu dikarenakan tanah gambut merupakan tanah yang berasal dari pelapukan pepohonan dan dedaunan. Selain itu gambut juga memiliki porositas yang besar sehingga kemampuan gambut untuk meloloskan air juga tinggi. Antar muka lapisan gambut dengan lapisan lempung pasiran memiliki reisitivitas sebesar $29 \Omega \mathrm{m}$ s.d $37 \Omega \mathrm{m}$ dari keempat lintasan.

Perpotongan antara Lintasan 2, Lintasan 3 dengan Lintasan 4 memberikan informasi terkait dengan pertemuan sebaran tanah gambut pada lokasi penelitian. Pada kedua titik perpotongan ini, lapisan gambut berada hingga kedalaman 5,6 m. Ketebalan tanah gambut yang sama pada pertemuan ketiga lintasan tersebut menandakan model yang dibuat dapat mendeteksi batas kedalaman tanah gambut.

Tanah gambut terdangkal terdapat pada Lintasan 2 yang berjarak $42 \mathrm{~m}$ dari titik mulamula lintasan tersebut. Ketebalan tanah gambut bervariasi mulai dari 3,7 hingga 7,91 m. Berdasarkan interpretasi masing-masing lintasan, ketebalan tanah gambut di lokasi penelitian berkisar 3,76 $\mathrm{m}$ hingga 7,91 $\mathrm{m}$.

Berdasarkan Gambar 6.d, tanah gambut yang terdalam berada di antara Lintasan 2 dan Lintasan 3 yakni hingga 7,91 m. Utami (2012) menyatakan bahwa ketebalan tanah gambut di Sungai Raya bervariasi mulai dari kedalaman 0,5 s.d $4 \mathrm{~m}$. Letak geografis kawasan sungai raya yang dilalui oleh sungai kapuas menyebabkan sebagian lahan di kawasan tersebut terbentuk dari endapan lumpur (delta) dan gambut.

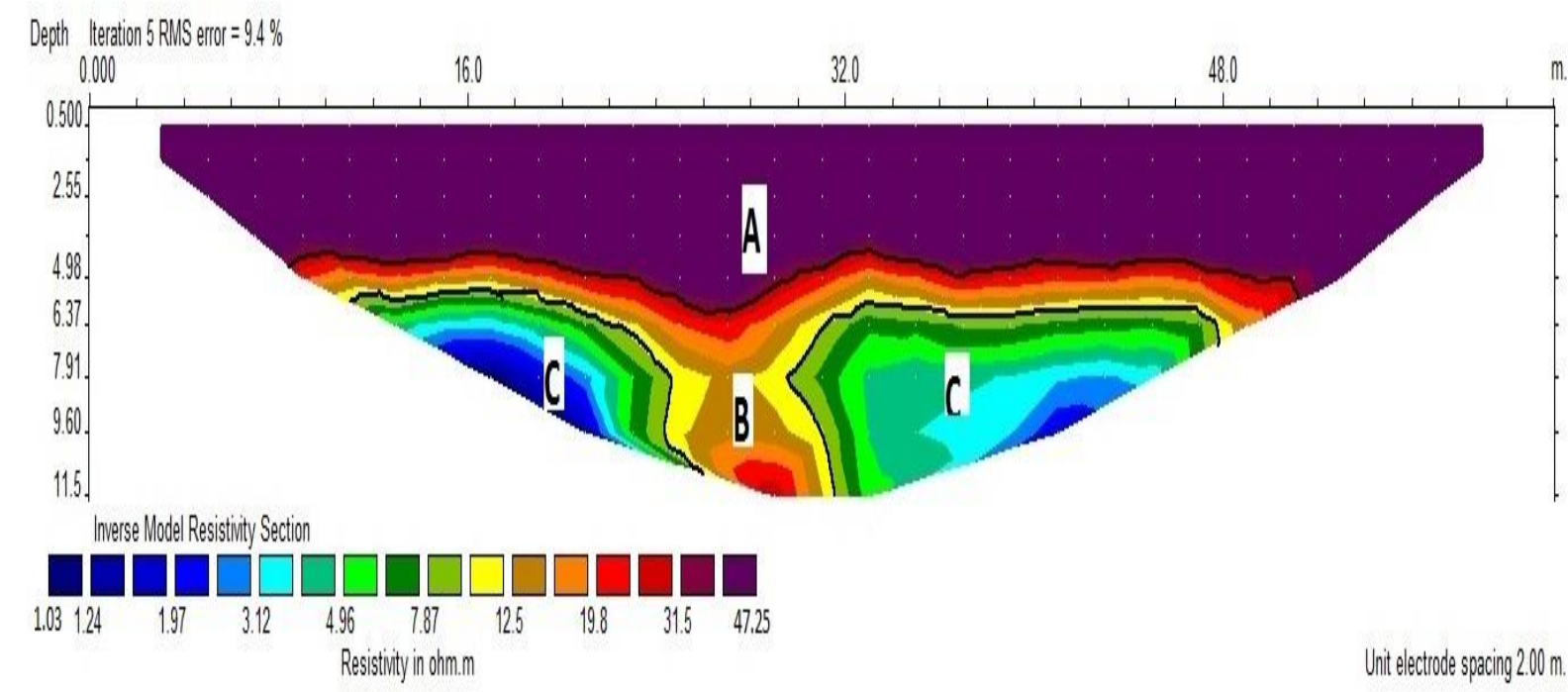

Gambar 6. Penampang resistivitas pada Lintasan 3 
Depth Heration 5 RUS erro $=6.5 \%$

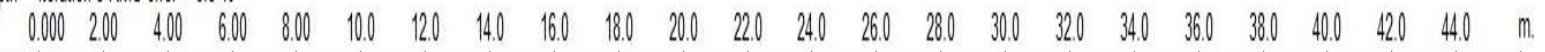
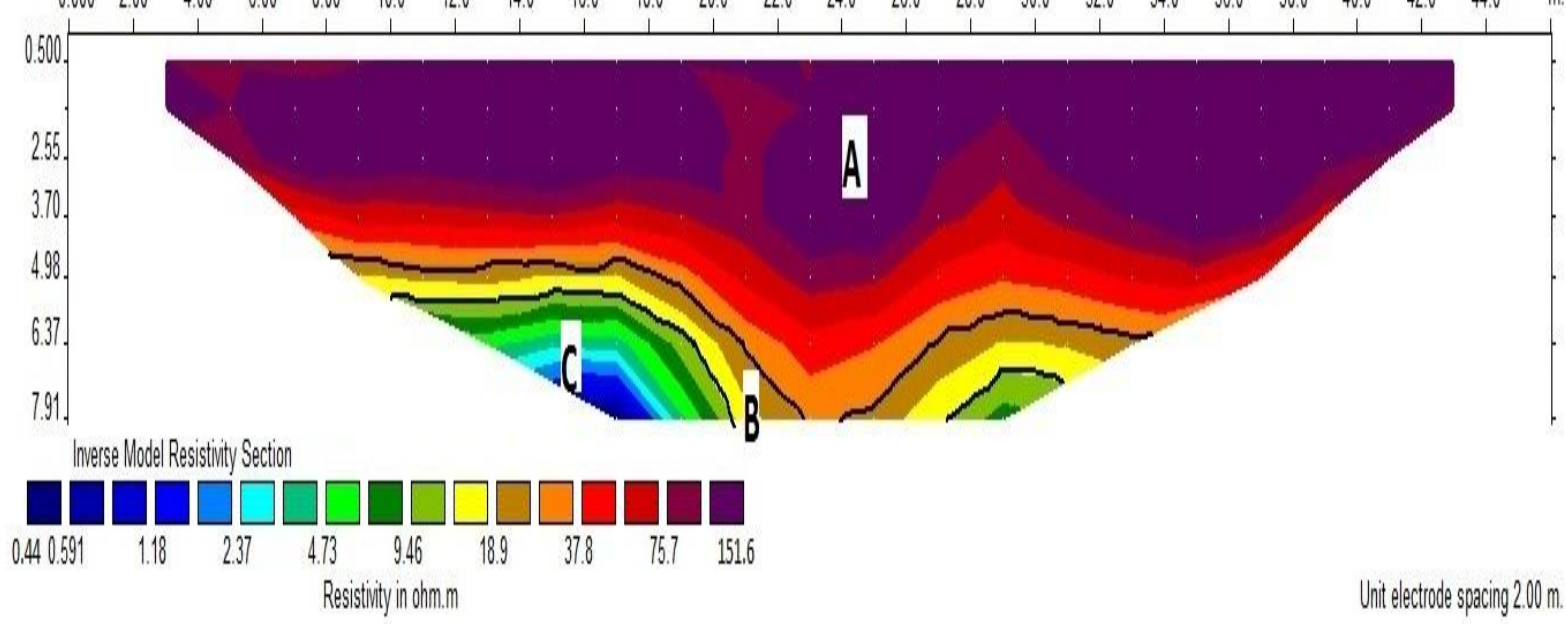

Unit electrode spacing $200 \mathrm{~m}$

Gambar 7. Penampang resistivitas pada Lintasan 4
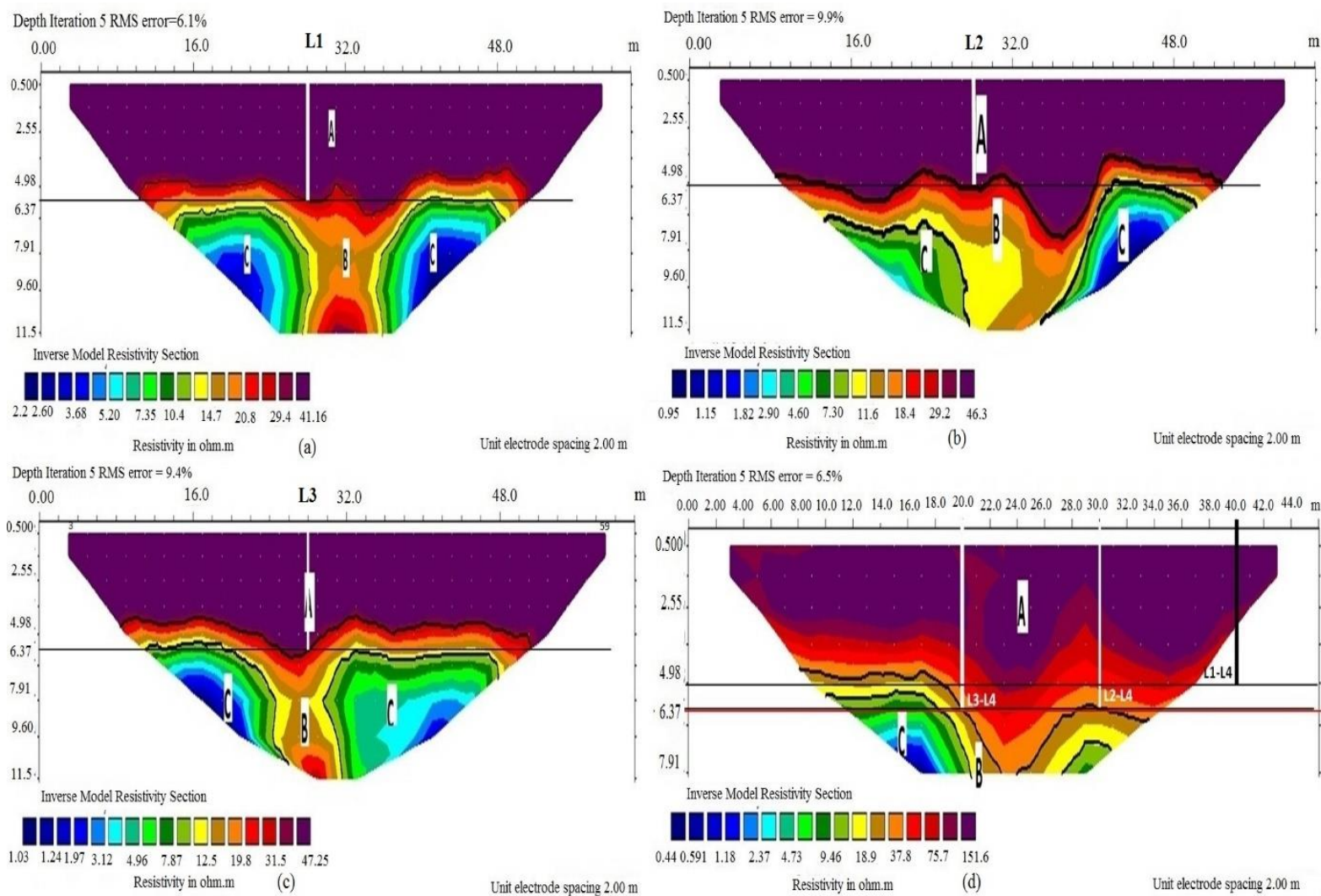

Depth Iteration 5 RMS error $=6.5 \%$

m $\quad 0.002 .004 .006 .008 .0010 .012 .014 .016 .018 .020 .022 .024 .026 .028 .030 .032 .034 .036 .038 .040 .042 .044 .0 \mathrm{~m}$

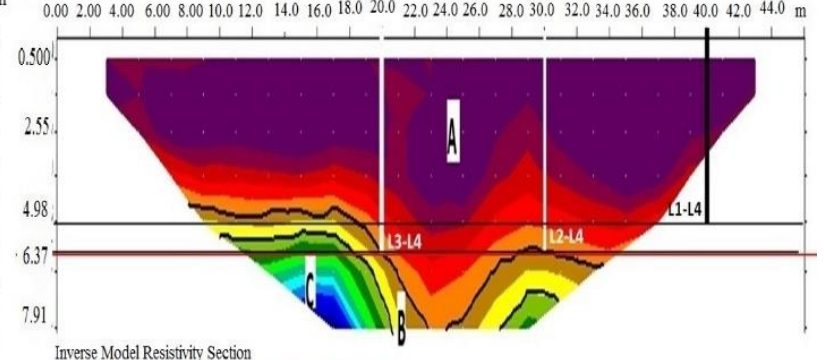

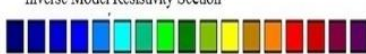

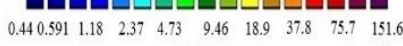

Unit electrode spacing $2.00 \mathrm{~m}$

Resistivity in ohm.m (d)

Unit electrode spacing $2.00 \mathrm{~m}$

Gambar 8. Titik perpotongan lintasan 1 (a), lintasan 2 (b), lintasan 3 (c), dan titik perpotongan antara lintasan 2, lintasan 3 dan lintasan 4 (d)

\section{Kesimpulan}

Berdasarkan Hasil penelitian dapat disimpulkan bahwa lapisan tanah gambut di komplek Korpri Sungai Raya Dalam Kabupaten Kubu Raya memiliki nilai resistivitas antara 29,4 hingga 151,6 $\Omega \mathrm{m}$. Sedangkan ketebalan lapisan tanah tanah gambut pada lintasan 1 hingga lintasan 4 bervariasi mulai dari 4 hingga 7,91 meter.

\section{DaftarPustaka}

[1] Wahyunto, S. R., Suparto, dan Subagyo, Sebaran Gambut dan Kandungan Karbon di Sumatera dan Kalimantan, Proyek Climate Change, Foresta, and Peatlands in Indonesia, Wetlands Internasional, Indonesia Programer and Widlife Habitat Canada, Bogor, 2005. 
[2] Sirait, F., dan Ihwan, A., Identifikasi Struktur Lapisan Tanah Gambut sebagai Informasi Awal Rancang Bangunan dengan Metode Geolistrik 3D, PRISMA FISIKA, 3(2), 36-40, 2015.

[3] Hidayat, R., dan Sampurno, J., Identifikasi Lokasi Bedrock Menggunakan Metode Geolistrik Konfigurasi Wenner sebagai Bahan Acuan Perancangan Pondasi Pembangunan Gedung di Daerah Sampit Kalimantan Tengah, PRISMA FISIKA, 3(2), 41-46, 2015.

[4] Telford, W.M., Geldart, L.P., dan Sheriff, Applied Geophysics, Cambridge University Press, London, 1976.

[5] , Applied Geophysics (2 ed), Cambridge University Press, London, 1990.

[6] Santoso, P., Arman, Y., dan Ihwan, I., Identifikasi Perubahan Nilai Resistivitas Tanah Gambut Akibat Penyemprotan Herbisida Sistem Kontak Menggunakan Metode Geolistrik Resistivitas Konfigurasi Dipole Dipole, PRISMA FISIKA, (3), 87-92, 2015.

[7] Pokja Sanitasi KKR, Buku Putih Sanitasi Kabupaten Kubu Raya Provinsi Kalimantan Barat, Kubu Raya, 2013.

[8] Utami, W.D., Status Keberlanjutan Tipologi Rumah Panggung pada Lahan Bergambut di Kawasan Sungai Raya Kabupaten Kubu Raya Kalimantan Barat, Vokasi, 8(2), 90-100, 2012. 